\title{
ДИНАМИКА ОСЫПЕЙ В ЦЕНТРАЛЬНОЙ ЧАСТИ ГОР ДЕЛ-УРЭКЧЭН (СеверНое ПриохоТЬе) НА ОСНОВЕ ЛИХЕНОМЕТРИЧЕСКИХ ДАННЫХ
}

\author{
Колегов П. П. \\ ФГБУН Северо-Восточный комплексный научно-исследовательский институт \\ им. Н. А. Шило ДВО РАН, г. Магадан \\ E-mail: kolegovpp@gmail.com
}

\begin{abstract}
Приведены результаты исследований по динамике осыпей в басс. pр. Аган и Нанкала (басс. p. Армань) с применением лихенометрического метода. Время экспонирования поверхности коллювиальных конусов составляет в среднем $385 \pm 114$ лет, скорость смещения обломочного чехла $-0.48 \pm 0.23$ м/год. Дистальные части некоторых конусов, приуроченные к скалистым склонам северной экспозиции, преобразованы в присклоновые каменные глетчеры.
\end{abstract}

Ключевые слова: коллювий, осыпь, каменный глетчер, лихенометрия, Северное Приохотье.

DOI: $10.34078 / 1814-0998-2021-3-71-81$

\section{ВВЕДЕНИЕ}

Склоновый морфолитогенез - это широкий комплекс процессов по преобразованию дневной поверхности горных стран, основным фактором его развития является сила гравитации. Развитие во времени и пространстве коллювиальных процессов ведет к возникновению многочисленных форм рельефа, таких как десерпционные склоны, обвалы, осыпи. При развитии склонового морфолитогенеза в криолитозоне происходит преобразование вышеназванных форм в солифлюкционные потоки, курумы, каменные глетчеры (КГ).

На территории Северного Приохотья, как и Северо-Востока Азии в целом, проблемы коллювиального рельефообразования рассмотрены слабо. В период 1940-1970-х гг. исследовательские работы были посвящены в основном проблемам оледенения и солифлюкции (Колосов, 1946; Сакс, 1947; Каплина, 1965). Начиная с 1970-х гг. рядом авторов стали раскрываться проблемы коллювиального и коллювиально-криогенного морфолитогенеза. В работах Э. Э Титова (1970, 1971, 1976) представлено общее описание морфологии склонов горных стран Северо-Востока Азии, доминирующих склоновых процессов, строение коллювия и основные этапы развития склонов. В его работах также дана оценка скорости смещения обломочного чехла для десерпционных и склонов, подверженных медленной солифлюкции, методом маркирования каменных полос. Так, показатели движения составили от

(C) Колегов П. П., 2021
20 до 200 мм/год (Титов, 1971, 1976). В. Л. Суходровским были рассмотрены вопросы криогенного рельефообразования на территории Якутии. Было отмечено, что в области развития многолетнемерзлых пород значительно увеличивается скорость протекания коллювиально-криогенных и криогенных процессов. Так, приведенные им данные скорости смещения обломков в результате десерпции и солифлюкции составляют от 10 до 30 мм/год для склонов крутизной 10-20 (Суходровский, 1979). В середине $1980-$ х гг. на территории Верхнеколымского нагорья были проведены исследования С. М. Говорушко, посвященные оценке скорости движения грубообломочных грунтов, методами экранов, траншей-ловушек, окрашиванием створов склонов и дендрохронологии. Полученные результаты для слоя мощностью 15-20 см составляют от 2-3 до 40-60 см/год (Говорушко, 1986).

Проведенные исследования носили в основном качественный характер с описанием единичных склонов, кроме работ В. Л. Суходровского, который проводил стационарные исследования в разных частях Якутии. Главным объектом изучения были десерпционные и солифлюкционные склоны, подверженные многолетнему промерзанию.

Исследователями не был затронут вопрос определения возраста коллювиальных отложений и времени их экспонирования.

Начиная с 2000-х гг. наступил новый этап в изучении склонового морфолитогенеза, связанный с использованием современных спутниковых снимков высокого разрешения и приме- 
нением количественных методов оценки динамики развития и времени экспонирования морфоскульптур. Рядом авторов проведены исследования по ледниковым формам рельефа и их взаимосвязи с коллювиальными отложениями (Смирнов и др., 2001; Глушкова и др., 2015; Глушкова, Смирнов, 2018), скальным оползням (Пахомов, Смирнов, 2002), палеосейсмодислокациям (Смирнов, Глушкова, 2015; Смирнов и др., 2018), динамике гравитиционных процессов и каменным глетчерам (Галанин, 2002, 2009; Галанин, Смирнов, 2004; Колегов, 2016, 2019), а также селям и обвалам в береговой зоне Охотского моря (Важенин, 2015, 2018; Смирнов и др., 2019).

Целью настоящей работы является оценка скорости движения обломочного материала в осыпях и определение времени экспонирования их поверхности в центральной части гор ДелУрэкчэн на основе собранных лихенометрических данных.

Вопрос определения времени экспонирования и скорости смещения обломочного чехла остается наиболее важным и мало изученным в геоморфологии в настоящий момент, так как требует использования либо классических (траншеи-ловушки, маркирование полос и др.) методов, которые является трудозатратными (длительные стационарные наблюдения), либо дорогостоящих изотопных методов $\left(\mathrm{He}^{3}, \mathrm{Be}^{10}\right.$, $\mathrm{Al}^{26}$ и др.) для датирования поверхности. Для достижения поставленной цели и получения количественных данных по изучаемым объектам мы применили лихенометрический метод, который начали использовать в геоморфологии с середины прошлого века (Beschel, 1957, 1973; Bull, Brandon, 1998; Галанин, 2002; Jomelli et al., 2007; и др.). Основные допущения этого метода следующие (Галанин, 2002): 1 - диаметр лишайника является функцией времени экспонирования поверхности, на которой он произрастает; 2 - колонизация лишайниками поверхности пород происходила достаточно быстро после образования обломков на склоне; 3 - время жизни определенных видов лишайниковых сообществ достигает пары тысяч лет, что позволяет их использовать в качестве индексов возраста поверхности склонов.

При исследованиях в качестве лишайникаиндикатора мы выбрали распространенный таксон Rhizocarpon sp., который был апробирован в регионе А. А. Галаниным (2002). Интервал жизни этого таксона может варьировать от 1 до 4 тыс. лет, для Северного Приохотья стадия уменьшения прироста таллома наступает при 2.0-2.5 тыс. лет, что всецело перекрывает диапазон датирования изучаемых нами объектов.

\section{РАЙОН, ОБЪЕКТЫ И МЕТОДЫ ИССЛЕДОВАНИЙ}

Район исследования расположен в центральной части гор Дел-Урэкчэн (рис. 1), в междуречье Аган - Нанкала (60²3' с. ш., $150^{\circ} 55^{\prime}$ в. д.). Рельеф территории среднегорный, с абсолютными высотами водораздельных пространств 1300 1500 м. Долины рек расположены на высоте 600-800 м. Относительное превышение рельефа составляет в среднем 300-500 м. Склоны гор покрыты маломощным чехлом коллювиальных отложений, местами в верхнем поясе гор имеются коренные выходы высотой от 2 до 15 м. Распространены склоны крутизной 25-35․

По генезису рельеф относится большей своей частью к выработанному (денудационный и экзарационный), в долинах крупных рек наблюдается аккумулятивный тип (Государственная..., 2001). Денудационный тип характерен для крутых склонов, которые образованы в результате интенсивных восходящих движений в неотектоническое время. Экзарационный тип представлен цирками, карами и троговыми долинами, образованными в результате зырянского и сартанского оледенений. Аккумулятивный тип рельефа выражен в основном аллювиальными отложениями, формирующими поймы и надпойменные террасы крупных рр. Нельканджа и Аган, а также ледниковыми и водно-ледниковыми отложениями. Наиболее распространенными морфоскульптурами территории являются десерпционные и волнистые склоны, коллювиальные и пролювиальные конусы выноса, морены, каменные глетчеры и курумы (Титов, 1976; Государственная..., 2001; Ландшафты..., 2006; Галанин, 2009; Колегов, 2016).

Территория сложена вулканогенными и осадочно-вулканогенными образованиями ОхотскоЧукотского вулканогенного пояса (ОЧВП), а также интрузивными комплексами, в незначительном количестве представлены терригенные породы. Петрографический состав материнских пород способствует образованию коллювия размерностью от мелкощебнистого до крупноглыбового.

Участки исследования расположены с таким учетом, чтобы характеризовать весь спектр геоморфологических обстановок территории (обычные склоны разных экспозиций, кары и каменные глетчеры), в которых проявлены изученные морфоскульптуры. Всего нами на территории проведено исследование четырех участков.

1. Участок «Кривуля». Основным геоморфологическим элементом является долина руч. Дуга длиной около 7 км. Гипсометрические уровни рельефа имеют следующие высотные отметки: долина ручья - от 900 до 1100 м; водоразделы 1200 м в нижнем течении, 1400-1500 м - в верховьях ручья; относительные превышения состав- 


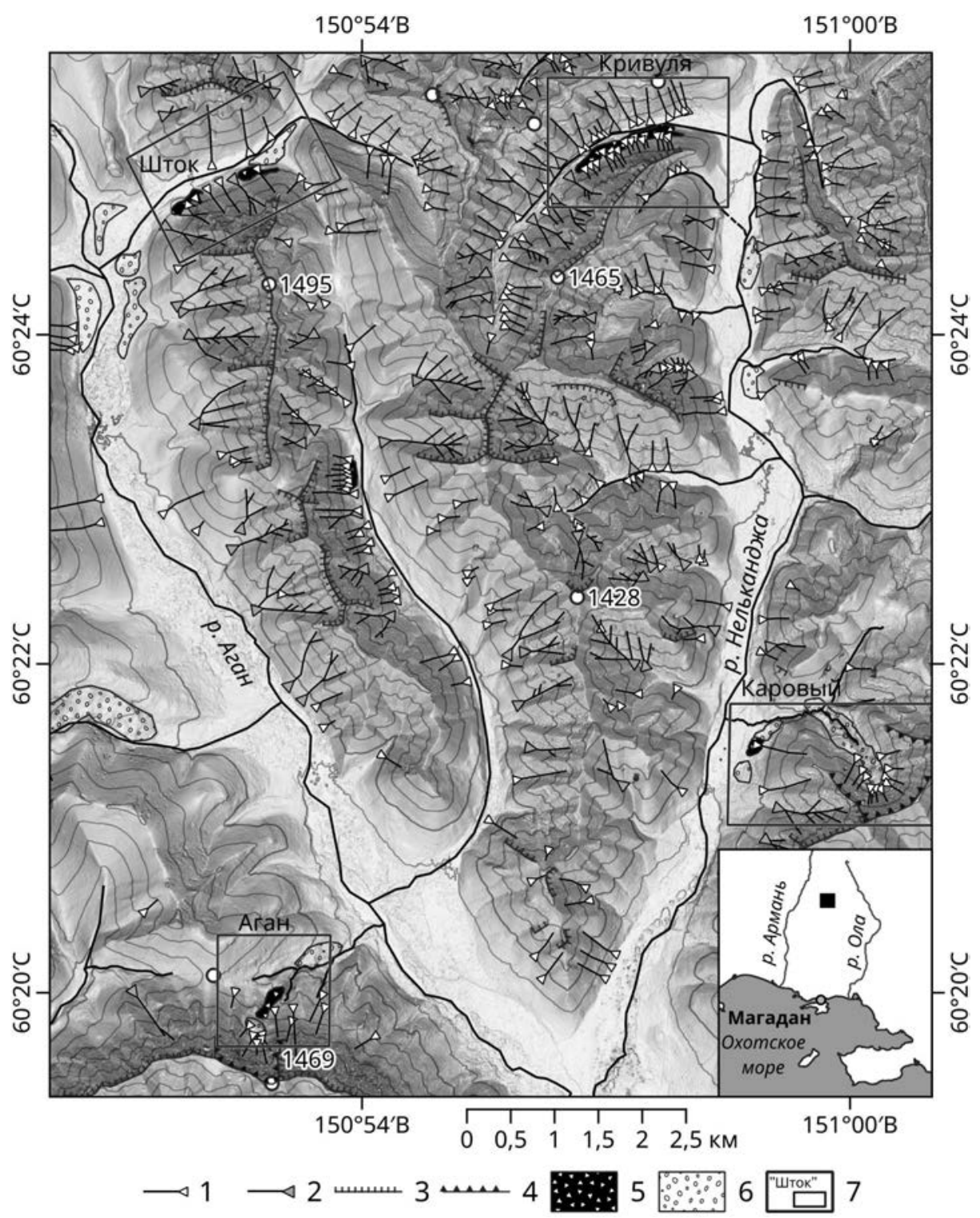

Puc. 1. Геоморфологическая схема района исследований. В качестве подложки использовано композитное изображение цифровой модели рельефа Arctic DEM (теневой рельеф + углы наклона). Горизонтали проведены через 100 м. Условные обозначения: 1 - осыпные конусы; 2 - лотковые конусы выноса; 3 - скалистые склоны; 4 - стенки каров; 5 - каменные глетчеры; 6 - моренные поля последнего позднеплейстоценового оледенения; 7 - участки исследований и их наименование. На врезке - географическое положение района работ

Fig. 1. Geomorphological outline of the research area. A composite image of the Arctic DEM digital elevation model (shadow relief + slope) was used as a substrate. The contours are drawn each $100 \mathrm{~m}$. Legend: $1-$ talus cones; $2-$ tray removal cones; 3 - rocky slopes; 4 -walls of kars; 5 -rock glaciers; 6 - moraine fields of the last Late Pleistocene glaciation; 7 - research sites and their names. The inset shows the geographic location of the work area

ляют 200-400 м. Горные склоны прямые, углы наклона достигают $32^{\circ}$.

Петрографический состав пород, слагающих участок и объекты исследования, представлен андезитами.

Более подробно геоморфологические и морфологические особенности участка описаны нами в работе (Колегов, 2016);

2. Участок «Шток». Характеризуется среднегорным рельефом. Горные склоны крутые (23$27^{\circ}$ ), в верхних частях скалистые. Высоты водораздельных пространств варьируют от 1350 до 1450 м. Гипсометрический уровень долины руч. Шток приурочен к 860-1000-метровому интервалу. Превышения над днищем долины колеблются от 350 до 500 м.

Петрографический состав пород, слагающих объекты исследования, представлен гранитами (осыпи) и андезитами (каменный глетчер);

3. Участок «Аган». Горные склоны крутые (24-28), верхний пояс преимущественно скалистый. Высотные отметки водораздела колеблются в интервале от 1350 до 1420 м, максимальная - 1469 м. Гипсометрический уровень 
долины ручья варьирует от 700 до 800 м. Расчлененность рельефа составляет $500 \mathrm{M}$.

Вещественный состав пород изученных морфоскульптур - туфы риолитов и риодацитов;

4. Участок «Каровый». Горные склоны крутые $\left(22-27^{\circ}\right)$, местами скалистые, обнаженность рельефа хорошая. Высотные отметки водораздельных частей варьируют от 1100 до 1300 м, максимальная - 1437.3 м. Расчлененность рельефа в среднем 250-350 м. Гипсометрический уровень долины р. Нанкала на территории участка составляет 680-720 м.

Петрографический состав пород, слагающих морфоскульптуры, - граносиениты.

Методы исследования включали в себя дешифрирование аэро- и космоснимков, геологогеморфологическое описание объектов при полевых наблюдениях. Для определения времени экспонирования поверхности применен лихенометрический метод.

Лихенометрический метод широко используется в мировой практике при геоморфологических исследованиях ледников, каменных глетчеров и других объектов, когда требуется установить возраст экспонированной поверхности (Beschel, 1957, 1973; Bull, Brandon, 1998; Галанин, 2002; Jomelli et al., 2007). В качестве лишайникаиндикатора был выбран таксон Rhizocarpon sp., так как его интервал жизни перекрывает интервал экспонирования изучаемых форм. Основные моменты применения метода и последующего анализа описаны нами в работе (Колегов, 2016).

Размеры площадок составляли в среднем $20 \times$ 20 м; на каждой площадке обследовалось не менее 100 случайно выбранных обломков горных пород. На каждом обломке измеряли наиболее крупную особь Rhizocarpon sp., точность измерения 1 мм. Площадки закладывали по профилям с учетом особенностей рельефа на морфоскульптурных поверхностях, однородных по петрографическому составу и размерности обломочного материала.

Полученную выборку из 100 измерений по каждому участку упорядочивали по убыванию и аппроксимировали убывающим логарифмическим трендом $(\mathrm{y}=\mathrm{a} \times \lg \mathrm{x}+\mathrm{b})$. В качестве значения максимального теоретического диаметра таллома принимался свободный член логарифмического тренда (так как при $\mathrm{x}=0, \mathrm{y}=\mathrm{b}$ ), который и использовался для расчета времени экспонирования поверхности.

Диаметр таллома пересчитан в возраст (для высоты 400-800 м н. у. м. (Галанин, 2002)) по уравнению:

$$
t=1000 \cdot \ln \left(-\frac{1}{d-230}\right)+5438.02,
$$

где $t$ - возраст таллома; $d$ - максимальный теоретический диаметр лишайника.

\section{РЕЗУЛЬТАТЫ}

В ходе полевых работ 2014-2017 гг. были заложены 13 лихенометрических профилей (35 т. н.) на четырех участках. Космоснимки объектов с вынесенными точками наблюдений приведены на рис. 2.

\section{Морфология коллювиальных конусов}

Участок «Кривуля» (рис. 2, а). Коллювиальные конусы имеют следующие параметры у изученных форм, м: длина от 135 до 540, средняя 295; ширина транзитных зон варьирует от 17 до 25 при среднем значении 20; ширина дистальных частей от 20 до 150 при среднем значении 45. Поверхность осыпей ровная, без вторичных изменений. Углы наклона транзитных частей 21-22, аккумулятивных $-17-19^{\circ}$. Область питания осыпей представлена различной морфологией - от обширной древовидной в северном борту долины до одиночных каналов стока, берущих начало от крупных коренных выходов в южном борту.

Гранулометрический состав осыпных конусов (6 шт.) в бассейне руч. Дуга представлен в дистальных частях крупным щебнем, в транзитных - средним щебнем.

На участке заложено 6 лихенометрических профилей (15 т. н.), из них 2 на поверхности каменного глетчера.

Участок «Аган» (рис. 2, б). Коллювиальные конусы, расположенные в стенках кара, имеют длину от 220 до 320 м, ширину транзитной зоны от 15 до 25 м, аккумулятивной зоны - от 30 до 60 м. Углы наклона поверхности осыпей равны $34-38^{\circ}$ в транзитной части и $18-25^{\circ}$ в дистальной. Область питания представлена узкими каналами, которые прорезают останцы коренных пород.

Гранулометрический состав поверхности коллювиального конуса в стенке кара в дистальной части представлен средними и крупными глыбами, а в транзитной - глыбами среднего размера.

На обвально-осыпном конусе близ фронтального уступа кара заложен лихенометрический профиль (т. н. 3-, 4-, 5-Аг). Второй профиль заложен в створе каменного глетчера.

Участок «Шток» (рис. 2, в). Коллювиальные конусы имеют ширину аккумулятивной части от 90 до 140 м, в транзитной части - 20-50 м; длина - от 250 до 660 м. Конусы перекрывают тыловой шов долины и нередко достигают ее тальвега, где подрезаются водотоками. Область питания хорошо развита, древовидная, представлена выходами коренных пород и останцами высотой до 3 м. Углы наклона поверхности следующие: аккумулятивной части $-12-18^{\circ}$, транзитной $24-26^{\circ}$.

Гранулометрический состав поверхностей изученных осыпных конусов (3 шт.) в аккумулятивных и транзитных частях представлен крупным щебнем. 

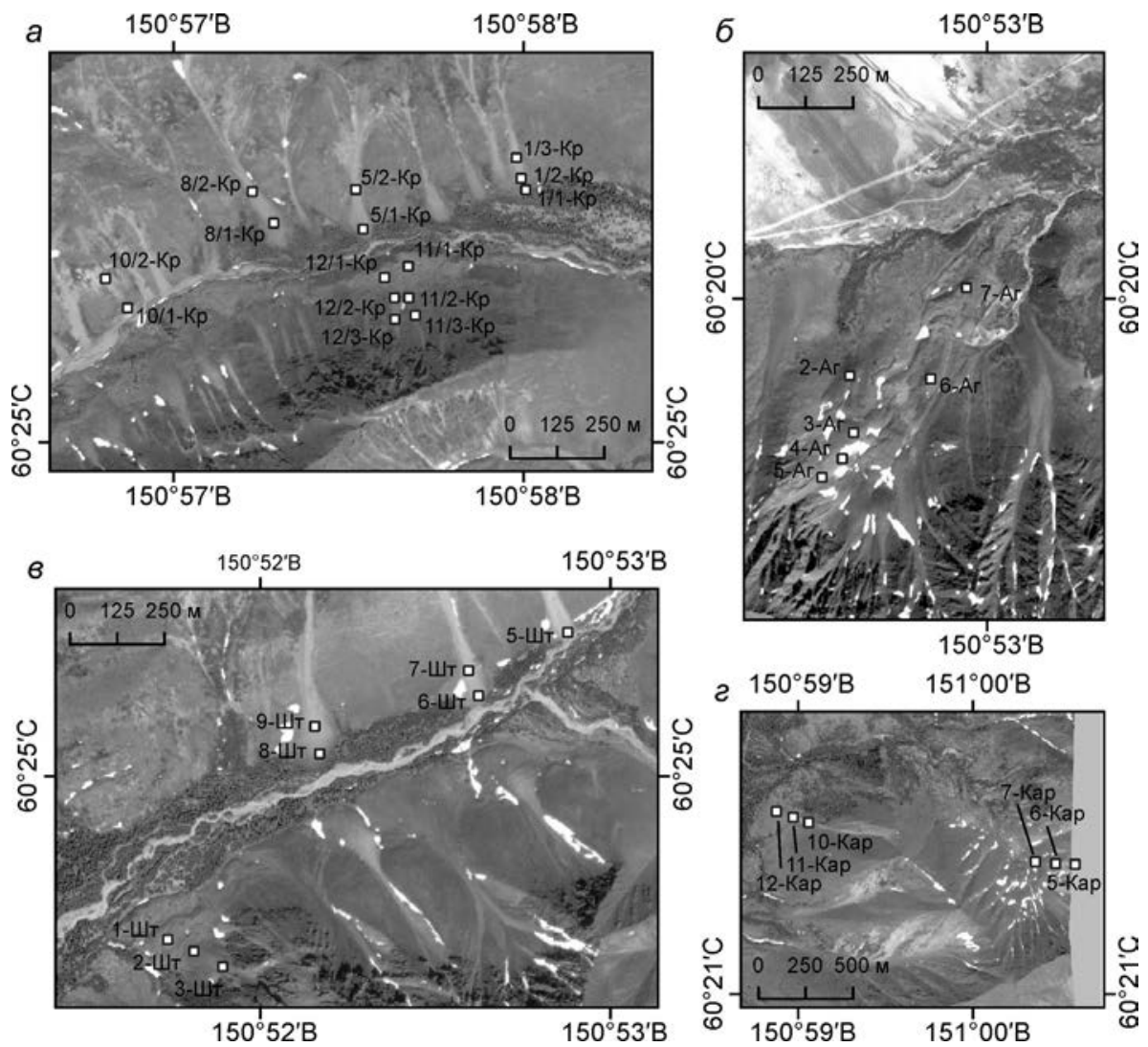

Puс. 2. Космоснимки участков исследований с вынесенными лихенометрическими площадками (белые квадраты). Участки: «Кривуля» $(a)$, «Аган» (б), «Шток» (в), «Каровый» (2) (картографические сервисы Яндекс и Google)

Fig. 2. Satellite images of research sites with lichenometric areas taken out (white squares). Sites: Krivulya (a), Agan (б), Shtok (6), Karovy (2) (Yandex and Google map services)

На участке заложены 3 лихенометрических профиля (7 т. н.), из них один на поверхности каменного глетчера.

Участок «Каровый» (рис. 2, г). Коллювиальные конусы, расположенные в стенке кара, имеют следующие морфометрические характеристики: длина от 166 до 439 м; ширина транзитной части от 10 до 30 м, дистальной - от 16 до 74 м. Углы наклона поверхности осыпей варьируют от 23 до $27^{\circ}$ в транзитной части и от 7 до $20^{\circ}$ в аккумулятивной (в зависимости от расположения относительно кара).

Длина осыпного конуса, питающего каменный глетчер, составляет 500 м, ширина транзитной части - 20 м, дистальной -50 м.

Гранулометрический состав отложений поверхностного слоя осыпей в транзитных частях представлен главным образом мелким щебнем, в аккумулятивных - средними глыбами.

Морфология каменных глетчеров

Участок «Кривуля». Присклоновый каменный глетчер расположен в правом борту руч. Дуга (рис. 3, $a$ ) и имеет длину 1.2 км (вдоль склона), ширину до 150 м, угол наклона поверхности КГ в сторону тальвега ручья 6-8․ Поверхность КГ представлена грядово-западинным рельефом.
Количество гряд в серии от 2 до 5; высота гряд составляет до 3 м. Превышение между фронтальной и тыловой частями 15-20 м. Более подробно он описан в статье (Колегов, 2016).

Гранулометрический состав поверхности представлен средними глыбами, в меньшей степени крупными.

Участок «Шток». Каменный глетчер расположен в левом борту руч. Шток и имеет северную экспозицию (рис. 3, б). Поверхность КГ, в его центральной части, представляет собой слабонаклонную поверхность $\left(6-8^{\circ}\right)$ в сторону тальвега ручья, которая осложнена невысокими грядами овальной формы, повторяющими контуры фронтального уступа. Длина объекта 200 м при ширине в 100 м. Всего нами выделены четыре гряды. В центральной части КГ наблюдается провал, образованный, скорее всего, в результате таяния ледяного ядра. Коллювиальный конус, питающий каменный глетчер, имеет ширину 60 м при длине 200 м, углы наклона поверхности в аккумулятивной части - 16-20, в транзитной $-26^{\circ}$.

Поверхность КГ представлена крупными и средними глыбами с крупнощебнистым заполнителем.

Участок «Аган». Каменный глетчер расположен на северо-восточном склоне горы 

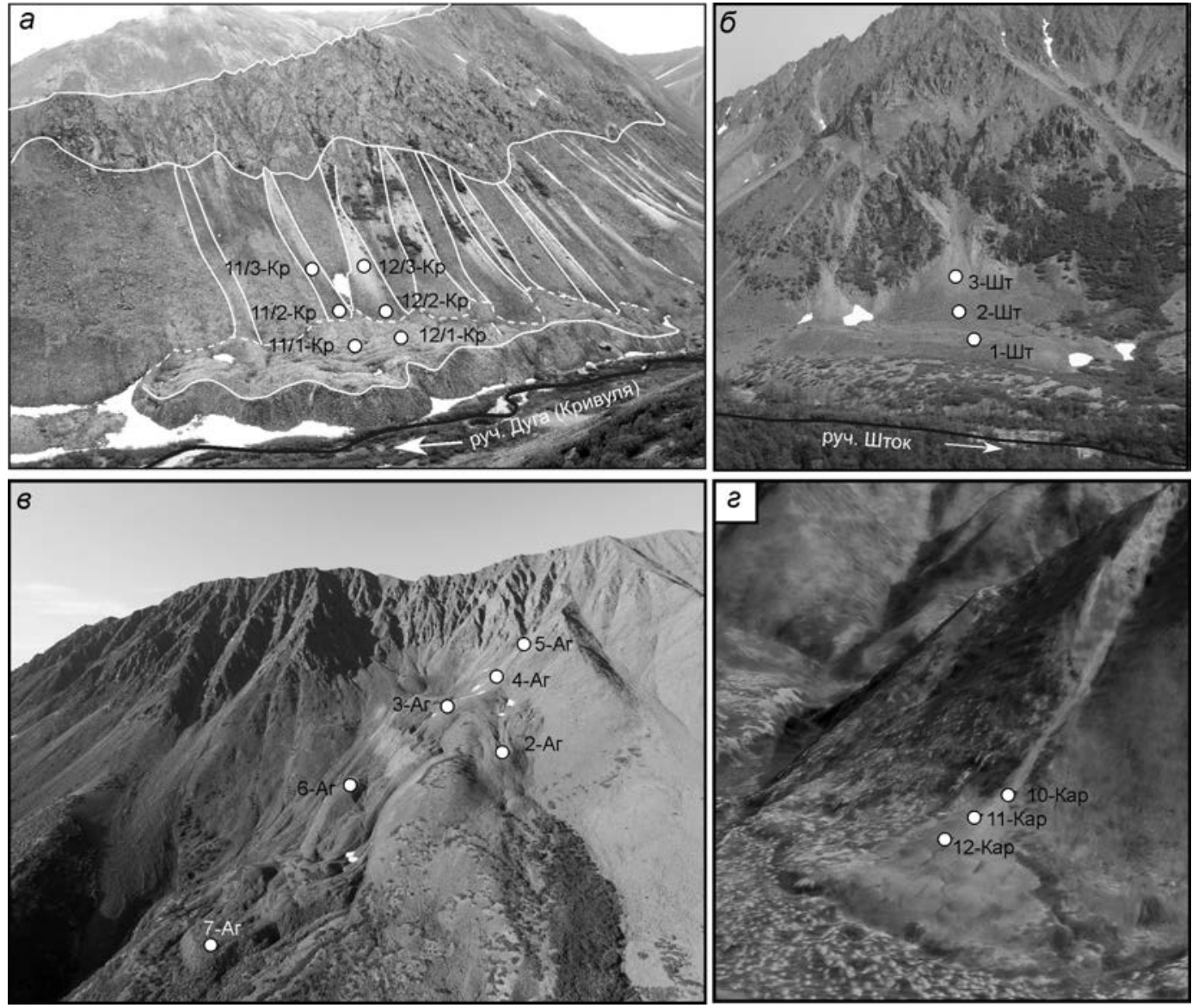

Puс. 3. Каменные глетчеры с вынесенными лихенометрическими площадками на участках «Кривуля» $(a)$, «Шток» (б), «Аган» (в) и «Каровый» (2) (3D модель с использованием космоснимка и Arctic DEM)

Fig. 3. Stone glaciers with removed lichenometric spots at the research sites: Krivulya (a), Shtok (б), Agan (b), Karovy (2) (3D model using a satellite image and Arctic DEM)

с высотной отметкой 1437 м (рис. 3,в). Его образование мы связываем с переработкой моренных отложений в каре северной экспозиции. Гипсометрическая характеристика кара следующая: верхняя бровка стенки кара - 1400 м; тыльный шов днища кара - 1100 м; фронтальный уступ днища - 1000 м; тыльный шов каменного глетчера - 960 м; фронтальный уступ КГ - 880 м.

Морфометрические характеристики КГ: длина - 600 м; ширина - от 100 до 140 м. Углы наклона поверхности следующие: поверхность каровой морены - 9-11 ; фронтальный уступ днища кара $-33^{\circ}$; тыльная часть КГ $-30^{\circ}$; фронтовая часть КГ $-22^{\circ}$. Поверхность КГ имеет грядовозападинный рельеф, высота гряд достигает 3-4 м при ширине 1.5-2.0 м, углы наклона поверхности гряд до $49^{\circ}$.

Поверхность КГ сложена глыбами крупного и среднего размера.

Участок «Каровый». По бортам долины p. Нанкала развиты осыпные конусы выноса как в простых формах, так и лотковых. Некоторые из них преобразованы в эмбриональные каменные глетчеры. Мы изучили одну из таких морфоскульптур.
Эмбриональный каменный глетчер (рис. 3, г) сформирован за счет преобразования боковой морены сартанского времени и накопления обломочного материала, поступающего с осыпи. Длина эмбрионального каменного глетчера составляет 150 м, ширина 200 м, высота фронтального уступа составляет 20-25 м. Поверхность представлена 3 рядами валов высотой от 2 до 5 м.

Гранулометрический состав обломков представлен средними глыбами.

\section{ОБСУЖДЕНИЕ}

В начале нашей дискуссии мы дадим определения терминам коллювий, коллювиальный процесс и морфолитогенез, поскольку в разной литературе (в том числе и справочной) приводятся их спорные значения. Коллювий - все склоновые отложения в целом (Шанцер, 1966. С. 56). Склоновый ряд состоит из следующих видов накоплений: 1) обвальных, 2) осыпных, 3) оползневых, 4) солифлюкционных, 5) делювиальных. Коллювиальный процесс - синонимичное определение склоновых процессов (Титов, 1971. С. 19; 1976. C. 15), образующих склоны путем смещения рыхлого материала вниз по склону под действи- 
ем, главным образом, сил гравитации с последующей его аккумуляцией в основании склона. Коллювиальный морфолитогенез - совокупность процессов морфо- и литогенеза на склонах (Титов, 1976).

Лихенометрический метод позволяет оценить время экспонирования поверхности, а с учетом имеющихся рассчитанных кривых роста для Rhizocarpon sp. (Галанин, 2002) имеется возможность получать калибровочный возраст поверхности согласно классификации, приведенной в работах (Colman et al., 1987; Палеосейсмология, 2011). Давайте обсудим, что означают получаемые датировки в срезе развития изучаемых нами коллювиальных морфоскульптур.

Большинство каменных поверхностей подвержено заселению лишайниковыми сообществами. Эти поверхности можно разделить условно на два типа: стабильные и динамически активные. Первые - относительно устойчивые к экзогенным процессам формы рельефа, такие как тектонические уступы и останцы, морены, инженерные сооружения и др. Время их экспонирования будет иметь одинаковые значения для всей поверхности морфоскульптуры. Полученные датировки относятся к калибровочному типу и отображают минимальное время образования поверхности. Второй тип поверхности - динамически активные, они постоянно обновляются вследствие их разрушения активными экзогенными процессами либо перекрытия более молодыми отложениями, либо за счет пересортировки. К данному типу можно отнести такие образования, как коренные стенки, щебнепокровные склоны, поймы рек, криогенные каменные кольца и др. При обновлении поверхности вышеназванных форм рельефа будут обновляться и произрастающие на них лишайниковые сообщества, что в свою очередь «обновляет» и возраст поверхности. Исходя из этого, мы будем именовать время полного обновления поверхности динамическим возрастом. Но стоит учитывать, что обновление поверхности происходит не только за счет экзогенных процессов, также возможны и случайные процессы (пожары, смыв почвы и др.), способствующие деградации почвенно-растительного покрова, при которой появляются новые каменистые поверхности.

Значение динамического возраста аккумулятивных частей коллювиальных морфоскульптур будет отображать не только время экспонирования поверхности, но и то, как активно протекают рельефообразующие процессы. Так, при малых значениях возраста можно говорить об активных склоновых процессах, способствующих накоплению обломочного материала. Большие значения отображают факты стабилизации рельефа или его частей. Оценивая возраст поверхности одной морфоскульптуры в разных ее частях (например, вверх по склону), мы можем оценить скорость транспортировки обломков. Так, одинаковые значения возраста в транзитной и аккумулятивной части осыпи говорит нам об одноактном процессе обновления поверхности (например, вследствие каменной лавины, быстрой солифлюкции, землетрясений и др.).

Заложенные лихенометрические профили позволили рассчитать скорость транспортировки обломочного материала в приповерхностном слое (не более 20 см) изучаемых морфоскульптур, а также динамический возраст данных форм.

Основные показатели лихенометрического анализа, возраст поверхности и скорость транспортировки обломков приведены в таблице.

Анализируя полученные данные, можно выделить следующие особенности в динамике изученных объектов.

Для аккумулятивных частей осыпей (с углами наклона 5-10) характерны малые значения скорости смещения обломочного чехла, а именно, м/год: профиль Аг-1 - 0.07, Кр-1 0.06 , Кар-1 - 0.12. Для транзитных зон скорость транспортировки обломков варьирует в широких пределах - от 0.18 до 0.79 м/год, при аномальных значениях у профилей Шт-2, -3 (1.86 и 1.75). Динамический возраст коллювиальных конусов варьирует от 248 до 549 лет, при аномальном значении у профиля Кр-10 (837 лет).

Значения скорости смещения обломочного материала можно проградуировать следующим образом: 1 - стабильные зоны аккумулятивных частей осыпей - до 0.10 м/год; 2 - зоны стабилизации поверхности - с 1.0 до 0.10 м/год; 3 - активные зоны транспортировки обломков - более $1.0 \mathrm{M} /$ год.

Среднемноголетние показатели смещения тел каменных глетчеров варьируют от 0.11 до 0.44 м/год. Минимальный возраст данных образований составляет, лет: «Кривуля» - 750, «Каровый» - 923 (тыловая часть), «Шток» - 993, «Аган»-1530. Мы относим их все к стабильным (деградированным) формам.

Полученные показатели динамического возраста и скорости позволяют оценить изученную нами территорию как область с активно протекающими коллювиальными процессами, при этом у единичных морфоскульптур наблюдается стабилизация поверхности, что скорее всего указывает на достижение ими профиля равновесия.

Полученные данные хорошо сопоставляются с уже имеющимися для другого района гор ДелУрэкчэн (на границе с Ольским плато), где скорость транспортировки обломочного материала в коллювиальных конусах варьирует от 0.39 до $0.85 \mathrm{~m} /$ год (Колегов, 2019). 
Таблица. Основные показатели лихенометрического анализа

Table. Main indicators of the lichenometric analysis

\begin{tabular}{|c|c|c|c|c|c|c|}
\hline Профиль & Площадка & $\begin{array}{c}\text { Наблюдаемый } \\
\text { диаметр таллома, } \\
\text { мм } \\
\end{array}$ & $\begin{array}{c}\text { Возраст поверх- } \\
\text { ности, лет }\end{array}$ & $\begin{array}{l}\text { Угол наклона } \\
\text { поверхности, }^{\circ}\end{array}$ & $\begin{array}{c}\text { Расстояние } \\
\text { между площад- } \\
\text { ками, м } \\
\end{array}$ & \begin{tabular}{|c|} 
Скорость \\
транспортиров- \\
ки, м/год \\
\end{tabular} \\
\hline \multicolumn{7}{|c|}{ Участок «Кривуля» } \\
\hline \multirow{4}{*}{ Kp-1 } & $1 / 1-\mathrm{Kp}$ & 115 & 684 & \multirow{2}{*}{10} & \multirow{2}{*}{24} & \multirow{2}{*}{0.06} \\
\hline & $1 / 2-K p$ & 48 & 275 & & & \\
\hline & $1 / 2-\mathrm{Kp}$ & 48 & 275 & \multirow{2}{*}{21} & \multirow{2}{*}{58} & \multirow{2}{*}{0.68} \\
\hline & $1 / 3-\mathrm{Kp}$ & 45 & 189 & & & \\
\hline \multirow{2}{*}{ Kp-5 } & $5 / 1-K p$ & 103 & 508 & \multirow{2}{*}{20} & \multirow{2}{*}{112} & \multirow{2}{*}{0.39} \\
\hline & $5 / 2-K p$ & 40 & 219 & & & \\
\hline \multirow{2}{*}{ Кр-8 } & 8/1-Кр & 90 & 462 & \multirow{2}{*}{23} & \multirow{2}{*}{108} & \multirow{2}{*}{1.09} \\
\hline & $8 / 2-K p$ & 70 & 363 & & & \\
\hline \multirow{2}{*}{ Kр-10 } & $10 / 1-\mathrm{Kp}$ & 129 & 837 & \multirow{2}{*}{21} & \multirow{2}{*}{103} & \multirow{2}{*}{0.19} \\
\hline & $10 / 2-\mathrm{Kp}$ & 62 & 304 & & & \\
\hline \multirow{4}{*}{ Kp-11 } & $11 / 1-\mathrm{Kp}^{*}$ & 120 & 712 & \multirow{2}{*}{10} & \multirow{2}{*}{118} & 035 \\
\hline & $11 / 2-\mathrm{Kp}$ & 70 & 379 & & & 0.53 \\
\hline & $11 / 2-K p$ & 70 & 379 & 26 & 46 & 033 \\
\hline & $11 / 3-\mathrm{Kp}$ & 45 & 241 & 20 & 40 & 0.33 \\
\hline & 12/1-Kp* & 122 & 750 & & & \\
\hline $\mathrm{Kn}_{-1}$ & $12 / 2-\mathrm{Kp}$ & 67 & 261 & 6 & 79 & 0.16 \\
\hline кр-12 & $12 / 2-\mathrm{Kp}$ & 67 & 261 & 28 & 57 & 079 \\
\hline & $12 / 3-\mathrm{Kp}$ & 44 & 189 & 20 & JI & 0.19 \\
\hline & & & Участок «Шт & К॥ & & \\
\hline & 1-Ш & 141 & 993 & & & \\
\hline$U_{m} 1$ & 2-Шт & 82 & 549 & 7 & 73 & 0.16 \\
\hline ШТ-1 & 2-Шт & 82 & 549 & 23 & 96 & 025 \\
\hline & 3-Шт & 36 & 163 & 23 & 90 & 0.25 \\
\hline UШТ_-2 & 6-Шт & 50 & 248 & 21 & & \\
\hline шт-2 & 7-Шт & 49 & 213 & 21 & 65 & 1.86 \\
\hline UIT_-3 & 8-Шт & 51 & 264 & 20 & 77 & 175 \\
\hline Ш1-5 & 9-Шт & 44 & 220 & 20 & 17 & 1.13 \\
\hline & & & Участок «Аг & & & \\
\hline & $5-\mathrm{A} \Gamma$ & 32 & 158 & 27 & 75 & 073 \\
\hline$A_{\Gamma_{-} 1}$ & 4-Аг & 55 & 258 & 21 & 15 & 0.13 \\
\hline Al-1 & 4-Аг & 55 & 258 & 8 & 76 & 007 \\
\hline & $3-\mathrm{A} \Gamma^{* *}$ & 137 & 1374 & $\delta$ & 10 & 0.01 \\
\hline$A_{\Gamma-2}$ & 7-А Г* & 158 & 1530 & 14 & 264 & 044 \\
\hline Al-2 & $6-\mathrm{A} \Gamma^{*}$ & 130 & 931 & & & 0.44 \\
\hline & & & Участок «Каро & зый» & & \\
\hline & 7-Кар** & 147 & 1228 & 12 & & 0 \\
\hline Kan 1 & 6-Кар & 61 & 383 & 12 & 101 & 0.12 \\
\hline nap-1 & 6-Кар & 61 & 383 & 23 & 70 & 051 \\
\hline & 5-Кар & 45 & 247 & 25 & 10 & 0.01 \\
\hline & 12-Кар* & 146 & 923 & 12 & 51 & 011 \\
\hline Kan-2 & 11-Кар & 92 & 467 & 12 & 31 & 0.11 \\
\hline Nap-2 & 11-Кар & 92 & 467 & 20 & 41 & 0.18 \\
\hline & 10-Кар & 51 & 237 & 20 & 41 & 0.10 \\
\hline
\end{tabular}

* Площадка заложена на поверхности каменного глетчера.

** Площадка заложена в основании коллювиального конуса, поверхность которого плавно переходит в поверхность каровой морены. 


\section{ВЫВОДЫ}

1. Скорость транспортировки обломочного материала в приповерхностном слое коллювиальных конусов по лихенометрическим данным варьирует от 0.18 до 0.79 м/год при среднем значении $0.48 \pm 0.23 \mathrm{м} /$ год.

2. Динамический возраст поверхности коллювиальных конусов колеблется от 248 до 549 лет при среднем значении $385 \pm 114$ лет.

3. Дистальные части некоторых конусов, приуроченные к скалистым склонам северной экспозиции, преобразовались в присклоновые каменные глетчеры находящиеся сейчас в стадии деградации.

\section{ЛИТЕРАТУРА}

Важенин Б. П. Экологические и техносферные последствия экстремальных ливней 2014 г. в Магадане // Технологии техносферной безопасности. 2015. № 2 (60). С. 263-276.

Важенин Б. П. Активизация обвально-оползневых процессов в Примагаданье в начале XXI века // Технологии техносферной безопасности. 2018. № 3 (79). C. 36-46.

Галанин А. А. Лихенометрия: современное состояние и направление развития метода (аналитический обзор). Магадан : СВКНИИ ДВО РАН, 2002. 74 с.

Галанин А. А. Каменные глетчеры Северо-Востока России: строение, генезис, возраст, географический анализ : дис. ... д-ра геогр. наук. Владивосток, 2009. $303 \mathrm{c.}$

Галанин А. А., Смирнов В. Н. Динамика гравитационных склоновых процессов в горах Северного Приохотья в позднем голоцене и лихенометрическая методика их моделирования и прогноза // Геоморфология. 2004. № 3. С. 67-75.

Глушкова О. Ю., Смирнов В. Н. Рельеф и коррелятные отложения позднего плейстоцена и голоцена в ледниковых долинах Килганских гор (ОхотскоКолымский регион) // Доклады АН. 2018. Т. 483, № 2. C. 206-211.

Глушкова О. Ю., Смирнов В. Н., Важенина Л. Н., Браун T. А. Развитие гляциальной и коллювиальной морфоскульптуры Килганских гор в позднем плейстоцене и голоцене (Охотско-Колымский регион) // Вестник СВНЦ ДВО РАН. 2015. № 3. С. 13-24.

Говорушко С. М. Курумовый морфолитогенез. Владивосток : ДВНЦ АН СССР, 1986. 120 с.

Государственная геологическая карта. Масштаб 1 : 200000 (новая серия). Лист Р-56-XXXI : объяснительная записка / под ред. И. И. Котляра, В. Н. Смирнова. Санкт-Петербург : КФ ВСЕГЕИ, 2001. 258 с. URL: http://geo.mfvsegei.ru/200k/p-56/p-56-31/index. html (дата обращения: 12.04.2020).

Каплина Т. И. Криогенные склоновые процессы. Москва : Наука, 1965. 296 с.

Колегов П. П. Динамика коллювиальных процессов в хребте Дел-Урэкчэн (Северное Приохотье) на основе лихенометрических данных // Вестник СВНЦ ДВО РАН. 2016. № 2. С. 10-18.

Поступила в редакцию 14.09.2020 2.

Поступила после доработки 23.07.2021 2.
Колегов П. П. Динамика осыпей и каменных глетчеров Ольского плато (Северное Приохотье) на основании лихенометрического и фотометрического гранулометрического анализов // Вестник СВНЦ ДВО РАН. 2019. № 3. С. 54-62.

Колосов Д. М. О развитии древнеледниковых ландшафтов Северо-Восточной Сибири // Труды Института геогр. АН СССР. 1946. С. 113-114.

Ландшафты, климат и природные ресурсы Тауйской губы Охотского моря / отв. ред. И. А. Черешнев. Владивосток : Дальнаука, 2006. 525 с.

Палеосейсмология : в 2-х т. / под ред. Дж. П. МакКалпина ; пер. с англ. 2-го изд. И. А. Басов и др. Москва : Научный мир, 2011. Т. 1. 560 с.

Пахомов А. Ю., Смирнов В. Н. Скальные оползни в горах Примагаданья // Геоморфология. 2002. № 3. C. 95-109.

Сакс В. Н. Четвертичное оледенение севера Сибири // Природа. 1947. № 4. С. 16-25.

Смирнов В. Н., Глушкова О. Ю. Сейсмодислокации - геоморфологические аномалии на фоне развивающегося экзогенного рельефа в хр. Улахан-Чистай (сейсмический пояс Черского) // Вестник СВНЦ ДВО PAH. 2015. № 4. C. 3-15.

Смирнов В. Н., Галанин А. А., Глушкова О. Ю., Пахомов А. Ю. Псевдосейсмодислокации в горах Примагаданья // Геоморфология. 2001. № 2. С. 81-92.

Смирнов В. Н., Горячев Н. А., Глушкова О. Ю. Новые данные о морфологии и динамике береговой зоны бухты Нагаева (Охотское море) // Вестник СВНЦ ДВО PAH. 2019. № 4. C. 47-54.

Смирнов В. Н., Кондратьев М. Н., Колегов П. П. Крупная палеосейсмодислокация в юго-восточной части сейсмического пояса Черского (Северное Приохотье) // Доклады АН. 2018. Т. 479, № 4. С. 422-425.

Суходровский В. Л. Экзогенное рельефообразование в криолитозоне. Москва : Наука, 1979. 280 с.

Титов Э. Э. Скорости перемещения обломочного материала на склонах гор Северо-Востока СССР // Вестник МГУ. География. 1970. № 4. С. 95-98.

Титов Э. Э. Строение и развитие склонов гор Северо-Востока СССР : автореф. дис. ... канд. геогр. наук. Москва, 1971. 35 с.

Титов Э. Э. Основные черты современного коллювиального морфолитогенеза в горах Северо-Востока СССР // Геоморфология. 1976. № 2. С. 11-25.

Шанщер E. B. Очерки учения о генетических типах континентальных осадочных образований. Москва : Наука, 1966. 240 с.

Beschel R. E. A project to use lichens as indicators of climate and time // Arctic. 1957. No. 1. P. 60.

Beschel R. E. Lichens as a measure of the age of recent moraines // Arctic and Alpine Research. 1973. Vol. 5, No. 4. P. 303-309.

Bull W., Brandon M. Lichen dating of earthquakegenerated regional rock-fall events, Southern Alps, New Zealand // GSA Bulletin. 1998. Vol. 110, No. 1. P. 60-84. Colman S., Pierce K., Birkeland P. Suggested Terminology for Quaternary Dating Methods // Quaternary Research. 1987. Vol. 28. P. 314-319.

Jomelli V., Grancher D., Naveau P., Cooley D., Brunstein D. Assessment study of lichenometric methods for dating surfaces // Geomorphology. 2007. Vol. 86, No. 1-2. P. 131-143. 


\title{
DYNAMICS OF COLLUVIAL CONES (TALUS) OF THE CENTRAL PART OF THE DEL-UREKCHEN MOUNTAINS (Northern Priokhotye) BASED ON LICHENOMETRIC DATA
}

\author{
P. P. Kolegov
}

\begin{abstract}
North-East Interdisciplinary Scientific Research Institute n. a. N. A. Shilo, FEB RAS, Magadan
The paper presents the results of the research on the colluvial cone (talus) dynamics study by using the lichenometric method in the basin of the Agan and Nankala rivers (Arman River basin). The obtained values of the exposure time of taluses are $385 \pm 114 \mathrm{yr}$, the displacement speed of the clastic cover in the talus is $0.48 \pm 0.23 \mathrm{~m} / \mathrm{yr}$. The distal parts of some cones, confined to the rocky slopes of the northern exposure, have been transformed into slope rock glaciers.
\end{abstract}

Keywords: colluvium, talus, rock glacier, lichenometry, Northern Priokhotye.

\section{REFERENCES}

Beschel, R. E., 1957. A Project to Use Lichens as Indicators of Climate and Time, Arctic. 10 (1), 60.

Beschel, R. E., 1973. Lichens as a Measure of the Age of Recent Moraines, Arctic and Alpine Research. 5 (4), 303-309.

Bull, W., Brandon, M., 1998. Lichen Dating of Earthquake-Generated Regional Rock-Fall Events, Southern Alps, New Zealand, GSA Bulletin. 110 (1), 6084.

Colman, S., Pierce, K., Birkeland, P., 1987. Suggested Terminology for Quaternary Dating Methods, Quaternary Research. 28, 314-319.

Federal Geological Map of the Russian Federation. Scale 1 : 200000 (New Series). P-56-XXXI. Ed. I. I. Kotlyar, V. N. Smirnov, 2001. Saint-Petersburg, MF VSEGII. URL: http://geo.mfvsegei.ru/200k/p-56/p-5631/index.html (Accessed 12.04.2020).

Galanin, A. A., 2002. Lichenometry: Current State and Direction of the Method Development (Analytical Review). Magadan, NEISRI FEB RAS [In Russian].

Galanin, A. A., 2009. Rock Glaciers in Russia's NorthEast: Structure, Genesis, Age, Geographical Analysis. Dis. ... Doktora Geogr. Nauk. Vladivostok [In Russian].

Galanin, A. A., Smirnov, V. N., 2004. Dynamics of Gravitational Slope Processes in the Mountains of the Northern Priokhotye and the Lichenometric Methodology of Reconstructing and Forecasting Them, Geomorphologiya. 3, 67-75 [In Russian].

Glushkova, O. Yu., Smirnov, V. N., 2018. Relief and Correlative Deposits of Late Pleistocene and Holocene in the Glacial Valleys of Kilgan Mountain, Okhotsk-Kolyma Region, Doklady Akademiyi Nauk. 483 (1), 1458-1462. Glushkova, O. Yu., Smirnov, V. N., Vazhenina, L. N., Brown, T. A., 2015. Development of Glacial and Colluvial Morphosculpture of the Kilgan Mountains during the Late Pleistocene and Holocene (Okhotsk-Kolyma Region), Vestnik NESC FEB RAS. 3, 13-24 [In Russian].

Govorushko, S. M., 1986. Corrom Morpholithogenesis. Vladivostok, DVNC AN USSR [In Russian].

Jomelli, V., Grancher, D., Naveau, P., Cooley, D., Brunstein, D., 2007. Assessment Study of Lichenometric Methods for Dating Surfaces, Geomorphology. 86 (1-2), 131-143.
Kaplina, T. I., 1965. Cryogenic Slope Processes, Moscow, Nauka [In Russian].

Kolegov, P. P., 2016. Dynamics of Colluvial Processes in the Del-Urekchen Ridge (Sea of Okhotsk Northern Coast) Based on Lichenometric Data, Vestnik NESC FEB RAS. 2, 10-18 [In Russian].

Kolegov, P. P., 2019. Dynamics of Colluvial Cones (Talus) and Rock Glaciers of the Ola Plateau (Northern Priokhotye) Based on Lichenometry and Photometric Particle Size Analysis, Bulletin of the North-East Science Center. 3, 54-62 [In Russian].

Kolosov, D. M., 1946. On the Development of Ancient Glacial Landscapes in Northeast Siberia, Proceedings of the Geographical Institute USSR Academy of Sciences. 113-114 [In Russian].

Landscapes, Climate and Natural Resources of the Tauy Bay of the Sea of Okhotsk, 2006. Ed. I. A. Chereshnev. Vladivostok, Dalnauka [In Russian].

Pakhomov, A. Yu., Smirnov, V. N., 2002. Rock Landslides in the Mountains of Primagadanye, Geomorphologiya. 3, 95-109 [In Russian].

Paleoseismology, 2016. Ed. J. P. McCalpin, 2nd edn. San Diego. Academic.

Saks, V. N., 1947. Quaternary Glaciation of the North of Siberia, Priroda. 4, 16-25 [In Russian].

Shantser, E. V., 1966. Essays on the Genetic Type Doctrine for Continental Sedimentary Formations. Moscow, Nauka [In Russian].

Smirnov, V. N., Galanin, A. A., Glushkova, O. Yu., Pakhomov, A. Yu., 2001. Pseudoseismic Dislocations in the Mountains of Primagadanye, Geomorphologiya. 2, 81-92 [In Russian].

Smirnov, V. N., Glushkova, O. Yu., 2015. Seismodislocations - Geomorphological Anomalies on the Background of Developing Exogenic Relief in the Ulakhan-Chistay Ridge (Chersky Seismic Belt), Vestnik NESC FEB RAS. 4, 3-15 [In Russian].

Smirnov, V. N., Goryachev, N. A., Glushkova, O. Yu., 2019. New Data on the Morphology and Dynamics of the Nagayev Bay Coastal Zone (Sea of Okhotsk), Bulletin of the North-East Science Center. 4, 47-54 [In Russian].

Smirnov, V. N., Kondratyev, M. N., Kolegov, P. P., 2018. A Large Paleoseismodislocation in the South-Eastern 
Part of the Cherskii Seismic Belt, Northern Priokhotye, Doklady Akademiyi Nauk. 479 (2), 425-428.

Sukhodrovsky, V.L., 1979. Exogenous ReliefFormation in the Cryolithozone. Moscow, Nauka [In Russian].

Titov, E. E., 1970. Velocities of Clastic Material Movement on the Slopes of the Mountains in the USSR North-East, MSU Vestnik. Geography. 4, 95-98 [In Russian].

Titov, E. E., 1971. The Structure and Development of the Slopes of the Mountains of the North-East of the USSR. Avtoref. Dis. ... Kandidata Geogr. Nauk. Moscow [In Russian].
Titov, E. E., 1976. Main Features of Modern Colluvial Morpholithogenesis in the Mountains of the USSR NorthEast, Geomorphologiya. 2, 11-25 [In Russian].

Vazhenin, B. P., 2015. Ecological and Technospheric Consequences of the 2014's Extreme Showers in Magadan, Technology of Technosphere Safety. 2, 263-276 [In Russian].

Vazhenin, B. P., 2018. Activation of Landslide Processes in Primagadanye at the Beginning of the $21^{\text {st }}$ Century, Technology of Technosphere Safety. 3, 36-46 [In Russian]. 